\begin{tabular}{c} 
PEDIOMATERNAL \\
NURSING JOURNAL \\
Vol. 5, No. 1, Maret 2019 \\
Jediomaternal \\
Journal Homepage: https://e-journal.unair.ac.id/PMNJ// \\
\hline
\end{tabular}

Original Research

\title{
Metode Role play Meningkatkan Pengetahuan dan Tindakan Pertolongan Pertama Luka Pada Anak Usia Sekolah Dasar di Daerah Rawan Bencana
}

\section{(The Role play Method Increasing Knowledge and First Action Injury in Elementary School of Children in Disaster-Prone Areas)}

\author{
Wirahadi Saputra, Ilya Krisnana, Iqlima Dwi Kurnia dan Tiyas Kusumaningrum \\ Fakultas Keperawatan, Universitas Airlangga, Surabaya, Jawa Timur, Indonesia
}

ARTICLE HISTORY
Received: March 17, 2019
Accepted: April 30, 2019
KEYWORDS
first aid; health education; role
play; student; wound
CORRESPONDING AUTHOR
Wirahadi Saputra
wirahadi.saputra-
2017@fkp.unair.ac.id
Fakultas Keperawatan,
Universitas Airlangga, Surabaya,
Jawa Timur, Indonesia

Cite this as:

\begin{abstract}
Introduction: Knowledge and skill of school age children is still lack about first aid of wound. The purpose of this study was to determine the effect of role play methodtowards knowledge and wound first aid skill on student. The aim of experiment is to study the effect of role play method towards knowledge and wound first aid skill on student.

Methods: The design used in this study was quasi-experimental quasi-eksperimental pretest-posttest control group design. The samples were gathered using simple random sampling method consisted of 50 students based on the inclusion criteria which were divided into experimental and control groups. The independent variable was health education using role play methods and the dependent variables were knowledge and first aid wound skill. The data were analyzed by using Wilcoxon Signed Rank Test and Mann Whitney U Test with level significance $\alpha \leq 0,05$.

Results: The Wilcoxon Signed Rank Test results showed that there were enhancement for knowledge $(\mathrm{p}=0.000)$ and first aid wound skill $(\mathrm{p}=0.000)$ for post intervention toward the experimental group. These data were strengthened by the result of Mann Whitney U Test statistical analysis that showed the significant differences for knowledge $(p=0.000)$ and action application of open wounds care $(\mathrm{p}=0.000)$.

Conclusion: It can be concluded that health education using role play methods affected knowledge and wound first aid skill on student. The suggestion for the further experiment is to compare role play methods with other health education methods to find out effective methods of health education for student.
\end{abstract}

Saputra, W., Krisnana, I., Kurnia, I. D., \& Kusumaningrum, T. (2019). Metode Role play Meningkatkan Pengetahuan dan Tindakan Pertolongan Pertama Luka Pada Anak Usia Sekolah Dasar di Daerah Rawan Bencana. Pediomaternal Nurs. J., 5(1), 89-98.

\section{PENDAHULUAN}

Definisi bencana menurut undang-undang Nomor 24 tahun 2007 tentang penanggulangan bencana yaitu peristiwa atau rangkaian peristiwa yang mengancam nyawa, mengganggu kehidupan dan penghidupan masyarakat yang disebabkan, baik oleh faktor alam dan atau faktor non alam maupun faktor manusia sehingga mengakibatkan timbulnya korban jiwa manusia, kerusakan lingkungan, kerugian harta benda, dan dampak psikologis. (1). Salah satu dampak akibat gempa adalah kerusakan pemukiman penduduk, sekolah dan sarana lainnya. Bangunan yang mengalami kerusakan yang berat bahkan rata dengan tanah menyisakan puing-puing atau bekas runtuhan bangunan. Lingkungan yang dipenuhi puing-puing bangunan yang rusak rentan mengakibatkan anak-anak mengalami cedera seperti tergores oleh puing-puing, terjatuh atau terpleset ketika bermain, mengingat masa anak usia sekolah adalah masa dimana anak membina hubungan dengan teman sebayanya dan energinya diarahkan untuk bermain dan mendapatkan pengetahuan (2).

Cedera dapat bersifat ringan hingga berat. Cedera ringan dapat ditangani secara sederhana di rumah, sedangkan cedera yang berat, setelah mendapat 
pertolongan pertama, harus dibawa ke rumah sakit. Dampak cedera dapat bersifat ringan hingga fatal, sebagai contoh yaitu tergoresnya bagian tubuh oleh benda tajam dapat berdampak ringan, seperti luka terbuka ukuran kecil. Namun, bila luka tidak segera dibersihkan dan ditutup, dapat mengakibatkan infeksi hingga kematian (3). Cedera akan sembuh tanpa komplikasi apabila segera mendapatkan penanganan yang tepat, namun apabila tidak tertangani dengan baik akan menimbulkan kecacatan hingga kematian (4). Secara global, cedera adalah penyebab kematian paling umum urutan ketiga pada anak-anak dan merupakan masalah utama. Lebih dari 660.000 anak usia 0-14 tahun meninggal akibat cedera pada tahun 2012. Cedera yang tidak disengaja (lalu lintas jalan, tenggelam, luka bakar, jatuh dan racun) menyebabkan sebagian besar kematian ini. Negara-negara berpenghasilan rendah dan menengah bertanggung jawab atas $90 \%$ dari semua kematian cedera yang tidak disengaja (5-44 tahun) (5).

Berdasarkan hasil studi pendahuluan didapatkan data melalui hasil wawancara kepala sekolah dan 10 murid SDN 2 Penimbung Kec. Gunung Sari, Kab. Lombok Barat yaitu bahwa siswa tidak pernah diajarkan tentang prosedur pertolongan pertama pada luka karena tidak adanya tenaga khusus yang mengajarkan dan 3 dari 10 orang siswa menjelaskan apabila mengalami lukatindakan yang mereka lakukan adalah membiarkan luka dan menunggu sampai sembuh, 2 orang menjelaskan apabila mengalami luka, tindakan yang dilakukan adalah membilas luka dengan air dan ditempel hansaplast (plester), dan 5 orang menjelaskan apabila mengalami luka tindakan pertama yang dilakukan adalah membilas luka dengan air saja. Responden mengatakan luka yang sering dialami adalah luka lecet akibat terjatuh saat bermain, luka iris karena terkena benda tajam seperti pisau, dan luka gores terkena benda disekitar tempat bermain.

Pengetahuan adalah hasil tahu dan terjadi setelah seseorang melakukan penginderaan terhadap suatu objek tertentu.Penginderaan terjadi melalui penginderaan manusia, yaitu indera penglihatan, pendengaran, penciuman, perasa dan peraba. Sebagian besar pengetahuan diperoleh melalui mata dan telinga (6). Menurut (7) pengetahuan seseorang antara lain dipengaruhi oleh faktor informasi, dengan adanya informasi baru mengenai suatu hal memberikan landasan kognitif baru bagi terbentuknya sikap terhadap hal baru tersebut. Informasi yang cukup baik dari berbagai media maka hal itu dapat meningkatkan pengetahuan seseorang. Hasil penelitian dari (8) pendidikan yang baik adalah pendidikan yang kelak dapat berguna di luar sekolah dan untuk kecakapan diri sendiri terutama dalam membantu siswa untuk mencapai kemandiriannya. Hal ini sejalan dengan penelitian (9) bahwa sebagian besar responden yang pengetahuannya kurang belum pernah mendapatkan informasi penanganan kegawatdaruratan secara lengkap dari sumber informasi formal. Berdasarkan hasil studi pendahuluan didapatkan data melalui hasil wawancara salah satu guru dan 10 murid SDN 2 Penimbung Kec. Gunung Sari, Kab. Lombok Barat bahwa siswa di SDN 2 Penimbung tidak pernah diajarkan cara melakukan pertolongan pertama pada luka yang sesuai prosedur oleh guru.

Pendidikan atau pelatihan tentang pertolongan pertama kepada semua orang sangat diperlukan, terutama bagi mereka yang kemungkinan sering berada dilingkungan rawan kecelakaan (10). Pengetahuan dasar P3K pada anak usia sekolah dasar sangat diperlukan supaya anak dapat mengenal P3K sederhana dan melakukan penanganan terhadap kecelakaan ringan yang dialaminya ataupun yang terjadi disekitarnya, mengingat anak dapat mengalami kecelakaan secara tiba-tiba, kapanpun dan dimanapun. Kesiagaan dan pengetahuan mengenai pertolongan pertama dalam menghadapi berbagai kemungkinan kecelakaan dan kejadian yang dapat mengancam hidup sangat diperlukan (3). Anak yang memiliki pengetahuan tentang penanganan dan keterampilan yang baik dalam melakukan penanganan luka dapat menolong dirinya sendiri sekaligus orang disekitarnya yang mengalami cedera. Pengetahuan dasar tentang penanganan luka terbuka penting untuk dimiliki anak-anak agar mereka dapat melindungi dan menangani diri sendiri saat mengalami cedera (11). Menurut (12) pada masa umur 10-12 tahun, anak berada dalam puncak perkembangan sehingga mudah untuk dibimbing, diarahkan dan ditanamkan kebiasaan yang baik.

Upaya peningkatan pengetahuan dan tindakan pertolongan pertama luka pada anak dapat diatasi dengan pendidikan kesehatan. Menurut (13) promosi kesehatan adalah segala bentuk kombinasi pendidikan kesehatan dan intervensi yang dirancang untuk memudahkan perubahan perilaku dan lingkungan yang kondusif bagi kesehatan. Pendidikan kesehatan yang dapat diterapkan pada anak usia sekolah adalah dengan metodebermain peran (role play). Memainkan suatu peran (role play) bertujuan untuk mendapatkan pandangan yang lebih luas terhadap suatu perilaku baru. Bermain peran dapat dilakukan dengan dua pendekatan, yaitu terstruktur dan spontanitas. Pendektan terstruktur menekankan proses belajar dengan cara mengobservasi, mempraktikan, menirukan (konseptualisasi), dan membagi pengalaman selama bermain peran (analisis). Pendekatan spontan lebih menekankan pada konseptualisasi tetapi meminimalkan analisis (14). Ada beberapa kelebihan dari metode roleplay (15) yaitu : 1) Dapat berkesan dengan kuat dan tahan lama dalam ingatan anak, disamping menjadi pengalaman yang menyenangkan juga memberi pengetahuan yang melekat dalam memori otak. 2) Mendorong keterlibatan peserta yang mendalam. 3) Membangkitkan pengertian, prasangka dan persepsi. 4) Memusatkan perhatian peserta pada aspek-aspek tertentu yang dikehendaki. 5) Mampu menumbuhkan dan meningkatkan minat belajar dalam suatu proses pembelajaran. Menurut (16), Metode role play merupakan metode pembelajaran yang melibatkan 
siswa secara aktif dalam bentuk drama yang diharapkan dapat mempermudah pemahaman siswa terhadap materi pembelajaran, dan mencapai tujuan pembelajaran.

\section{METODE}

\subsection{Desain}

Penelitian yang dilakukan merupakan jenis penelitian quasi-eksperimental pretest-posttest control group design.

\subsection{Populasi, sampel, dan sampling}

Populasi dalam penelitian ini adalah anak kelas 4,5, dan 6 SDN 2 Penimbung Kec. Gunung Sari Kab. Lombok Barat dengan jumlah 58 siswa. Sampel dalam penelitian ini adalah sebanyak 50 siswa dengan pembagian 25 pada kelompok perlakuan dan 25 pada kelompok kontrol dan menggunakan simple random sampling.

\subsection{Variabel}

Variabel independen dalam penelitian ini adalah pendidikan kesehatan metode role play. Variabel dependen dalam penelitian ini adalah pengetahuan dan tindakan siswa mengenai pertolongan pertama pada luka.

\subsection{Instrumen}

Kuesioner pengetahuan siswa tentang pertolongan pertama pada luka terdapat 35 pertanyaan. Peneliti menggunakan kuesioner dengan skala data ordinal untuk mengetahui pengetahuan sebelum dan sesudah intervensi pendidikan kesehatan dengan metode role play. Kategori baik (76\%-100\%), cukup (56\%-75\%), dan kurang (<56\%). Kuesioner untuk pengetahuan terdiri dari pertanyaan closed ended multiple choice yang bila dijawab dengan benar maka skor 1 dan bila salah skor 0 . Tindakan sebelum dan sesudah intervensi diukur menggunakan lembar observasi menurut Pedoman Pertolongan Pertama PMI tahun 2008 dengan skala data ordinal yang terdiri dari dari 6 langkah dalam melakukan pertolongan pertama. Instrumen lainnya yang digunakan dalam penelitian ini adalah alat dan bahan yang akan digunakan untuk menunjang kegiatan penelitian seperti naskah role play tentang pertolongan pertama pada luka, alat dan bahan PP menurut Pedoman Pertolongan Pertama (PMI) adalah betadin, gunting, kassa steril, kassa gulung dan plester.

\subsection{Prosedur}

Peneliti menjelaskan tujuan serta prosedur penelitian yang dilakukan di sekolah tersebut dan berkoordinasi dengan guru masing-masing wali kelas mengenai jadwal penelitian dan teknis penelitian. Sebelum memulai penelitian, peneliti menyeleksi siswa yang sesuai dengan kriteria inklusi dan eksklusi agar peneliti dapat menjaga tingkat homogenitas. sampel sebanyak 50 responden menggunakan teknik simple random sampling yang diambil dari kelas 4, 5 dan 6 dan terbagi menjadi 2 kelompok yaitu kelompok perlakuan dan kelompok kontrol.

Peneliti meminta persetujuan sebagai responden dengan memberikan informed consent ditanda tangani oleh orang tua sebagai wali dan lampiran data demografi pada semua siswa yang menjadi responden. Lembar informed consent dan data demografi dibawa pulang dan dikumpulkan keesokan harinya dikumpulkan di guru wali kelas. Peneliti memberikan naskah role play untuk dipelajari terlebih dahulu oleh responden kelompok perlakuan. Peneliti mengambil dan mengecek kembali lembar informed consent dan lampiran data demografi yang sudah diisi oleh responden dan menanyakan kembali pada responden apabila ada yang belum diisi lengkap.

Pengambilan data awal (pre test) dilakukan berdasarkan kelompok perlakuan dan kontrol diruangan kelas yang berbeda. Pre test pengetahuan tentang pertolongan pertama pada luka dilakukan dengan cara memberikan kuesioner kepada responden. Pengisian kuesioner dipandu oleh peneliti dengan cara memberikan penjelasan singkat mengenai cara pengisian. Pre test tindakan dilakukan dengan cara responden dipanggil satu per satu oleh peneliti dan meminta mempraktekan cara melakukan pertolongan pada luka terbuka. Peneliti meminta bantuan kepada wali kelas untuk berperan sebagai pasien untuk semua kelompok role play. Setelah dilakukan pre test, Intevensi pendidikan kesehatan metode role play diberikan sebanyak 3 kali pertemuan pada hari yang berebeda dengan tema naskah role play yang berbeda-beda. Intervensi pendidikan kesehatan metode role play pada hari pertama dengan tema "Pertolongan pertama", hari kedua dengan tema " Apa itu luka", dan hari ketiga dengan tema "Merawat luka".

Responden kelompok perlakuan berjumlah 25 orang dan dibagi menjadi 4 kelompok dan tersisa 1 orang. 1 orang ini dimasukkan kedalam kelompok yang sudah ada dan menggantikan salah satu anggota kelompok, setelah itu melakukan role play dengan tema yang sudah ditentukan oleh peneliti. Setelah intervensi selesai diberikan, peneliti melakukan post test mengenai pengetahuan dan tindakan penanganan luka terbuka pada kelompok perlakuan dan kelompok kontrol. Post test dilakukan 2 hari setelah diberikan intervensi. Kelompok kontrol diberikan pendidikan kesehatan di ruang kelas yang berbeda dengan kelompok perlakuan.

\subsection{Analisis}

Penelitian ini dilakukan analisis dengan IBM SPSS Statistic 21 dengan uji Wilcoxon Signed Rank Test with significant $\alpha \leq 0.05$ dan uji Mann Whitney $U$ Test with significant $\alpha \leq 0.05$

\subsection{Ethical Clearance}

Penelitian ini telah dinyatakan lolos kajietik dan mendapatkan sertifikat Ethical Approval dengan No. 1238-KEPK yang dikeluarkan oleh Komite Etik Penelitian Kesehatan Fakultas Keperawatan 
Universitas Airlangga pada tanggal 27 Desember 2018.

\section{Hasil}

Karakteristik responden, sebagian besar umur ratarata responden sama antara kelompok perlakuan dan kelompok kontrol yaitu ini ber umur 11 tahun. Jenis kelamin sebagian besar responden yaitu laki-laki sebanyak 14 anak (56\%) pada kelompok perlakuan dan 14 anak (56\%) pada kelompok kontrol. Pendidikan ayah sebagian besar responden yaitu SMP sebanyak 13 anak (52\%) pada kelompok perlakuan dan sebagian besar responden yaitu SMA sebanyak
14 anak (56\%) pada kelompok kontrol. Pendidikan ibu sebagian besar responden yaitu SMP sebanyak 14 anak (56\%) pada kelompok perlakuan dan sebagian besar responden yaitu SMP sebanyak 12 anak (48\%) pada kelompok kontrol. Pekerjaan orang tua responden sebagian besar bekerja sebagai petani yaitu 15 anak (60\%) pada kelompok perlakuan dan 14 anak (56\%) pada kelompok kontrol. Penghasilan orang tua responden sebagian besar yaitu $<1.400 .000$ sebanyak 22 anak (88\%) pada kelompok perlakuan dan sebanyak 15 anak (60\%) pada kelompok kontrol. Seluruh responden pernah mengalami luka. Penyebab luka rata-rata sama antara kelompok perlakuan dan kelompok kontrol yaitu jatuh.

Tabel 1. Karakteristik responden penelitian pengaruh metode role play terhadap pengetahuan dan tindakan pertolongan pertama luka pada anak usia sekolah dasar di SDN 2 Penimbung Kec. Gunung Sari Kab. Lombok barat

\begin{tabular}{|c|c|c|c|c|}
\hline \multirow{2}{*}{ Karakteristik } & \multicolumn{2}{|c|}{ Kelompok Perlakuan } & \multicolumn{2}{|c|}{ Kelompok Kontrol } \\
\hline & f & $\%$ & $\mathbf{f}$ & $\%$ \\
\hline \multicolumn{5}{|l|}{$\underline{\text { Umur }}$} \\
\hline 10 tahun & 8 & 32 & 7 & 28 \\
\hline 11 tahun & 9 & 36 & 9 & 36 \\
\hline 12 tahun & 8 & 32 & 9 & 36 \\
\hline Total & 25 & 100 & 25 & 100 \\
\hline \multicolumn{5}{|l|}{ Jenis kelamin } \\
\hline Laki-laki & 14 & 56 & 14 & 56 \\
\hline Perempuan & 11 & 44 & 11 & 44 \\
\hline Total & 25 & 100 & 25 & 100 \\
\hline \multicolumn{5}{|l|}{ Pendidikan Ayah } \\
\hline SD & 5 & 20 & 1 & 4 \\
\hline SMP & 13 & 52 & 8 & 32 \\
\hline SMA & 7 & 28 & 14 & 56 \\
\hline S1 & 0 & 0 & 2 & 8 \\
\hline Total & 25 & 100 & 25 & 100 \\
\hline \multicolumn{5}{|l|}{ Pendidikan Ibu } \\
\hline SD & 8 & 32 & 3 & 12 \\
\hline SMP & 14 & 56 & 12 & 48 \\
\hline SMA & 3 & 12 & 8 & 32 \\
\hline S1 & 0 & 0 & 2 & 8 \\
\hline Total & 25 & 100 & 25 & 100 \\
\hline \multicolumn{5}{|l|}{ Pekerjaan Orang Tua } \\
\hline PNS & 0 & 0 & 2 & 8 \\
\hline Petani & 15 & 60 & 14 & 56 \\
\hline Swasta & 7 & 28 & 7 & 28 \\
\hline Pedagang & 3 & 12 & 2 & 8 \\
\hline Total & 25 & 100 & 25 & 100 \\
\hline \multicolumn{5}{|l|}{ Penghasilan Orang Tua } \\
\hline$<1.400 .000$ & 22 & 88 & 15 & 60 \\
\hline$>1.400 .000$ & 3 & 12 & 10 & 40 \\
\hline Total & 25 & 100 & 25 & 100 \\
\hline \multicolumn{5}{|l|}{ Mengalami Luka } \\
\hline $\mathrm{Ya}$ & 25 & 100 & 25 & 100 \\
\hline Tidak & 0 & 0 & 0 & 0 \\
\hline Total & 25 & 100 & 25 & 100 \\
\hline \multicolumn{5}{|l|}{ Penyebab Luka } \\
\hline Jatuh & 18 & 72 & 18 & 72 \\
\hline Terkena benda tajam/tumpul & 7 & 28 & 7 & 28 \\
\hline Total & 25 & 100 & 25 & 100 \\
\hline \multicolumn{5}{|c|}{ Mendapat Informasi Penanganan Luka } \\
\hline Pernah & 3 & 12 & 2 & 8 \\
\hline Tidak pernah & 22 & 88 & 23 & 92 \\
\hline Total & 25 & 100 & 25 & 100 \\
\hline
\end{tabular}


Sebagian besar responden tidak pernah mendapatkan informasi penanganan luka baik kelompok perlakuan maupun kelompok kontrol [Tabel 1].

Pengetahuan responden mengenai pertolongan pertama pada luka, sebagian besar responden kelompok perlakuan saat pada pre test berpengetahuan kurang yaitu sebanyak 22 anak (88\%), sedangkan pada saat post test sebagian besar responden berpengetahuan cukup yaitu sebanyak 18 anak (72\%). Setelah dilakukan uji Wilcoxon sign rank testdidapatkan nilai $\mathrm{p}=0,000(\mathrm{p}<0,05)$ artinya ada perbedaan pengetahuan yang signifikan saat pre test dan post test. Sedangkan untuk kelompok kontrol yang signifikan saat pre test dan post test. Sedangkan untuk kelompok kontrol menunjukkan bahwa seluruh responden belum dapat melakukan tindakan penanganan luka terbuka pada saat pre test. Hasil post test menunjukkan responden masih belum bisa melakukan tindakan penangan luka terbuka dengan baik. Setelah dilakukan uji wilcoxon sign rank test didapatkan nilai $\mathrm{p}=1,000(\mathrm{p}>0,05)$ artinya tidak ada perbedaan tindakan yang signifikan saat pre test dan post test. Hasil uji Mann Whitney U Test pada post test tindakan kelompok perlakuan dan kelompok kontrol didapatkan nilai $p=0,000(p<0,05)$ artinya terdapat perbedaan tindakan yang signifkan antara kelompok perlakuan dan kelompok kontrol [Tabel 3].

Tabel 2. Pengetahuan responden mengenai pertolongan pertama luka sebelum dan sesudah pendidikan kesehatan metode role play di SDN 2 Penimbung Kec. Gunung Sari Kab. Lombok Barat

\begin{tabular}{|c|c|c|c|c|c|c|c|c|}
\hline \multirow{3}{*}{ Pengetahuan } & \multicolumn{4}{|c|}{ Kelompok Perlakuan } & \multicolumn{4}{|c|}{ Kelompok Kontrol } \\
\hline & \multicolumn{2}{|c|}{ Pretest } & \multicolumn{2}{|c|}{ Posttest } & \multicolumn{2}{|c|}{ Pretest } & \multicolumn{2}{|c|}{ Posttest } \\
\hline & f & $\%$ & f & $\%$ & f & $\%$ & f & $\%$ \\
\hline Baik & 0 & 0 & 7 & 28 & 0 & 0 & 0 & 0 \\
\hline Cukup & 3 & 12 & 18 & 72 & 2 & 8 & 2 & 8 \\
\hline Kurang & 22 & 88 & 0 & 0 & 23 & 92 & 23 & 92 \\
\hline total & 25 & 100 & 25 & 100 & 25 & 100 & 25 & 100 \\
\hline \multicolumn{3}{|c|}{ Uji Wilcoxon sign rank test } & \multirow{2}{*}{\multicolumn{2}{|c|}{$\mathrm{p}=0,000$}} & & & \multirow{2}{*}{\multicolumn{2}{|c|}{$p=0,671$}} \\
\hline Uji Mann Whitne & Test & & & & 0,000 & & & \\
\hline
\end{tabular}

Tabel 3. Tindakan responden kelompok perlakuan mengenai pertolongan pertama pada luka sebelum dan sesudah pendidikan kesehatan metode role play di SDN 2 Penimbung Kec. Gunung Sari Kab. Lombok Barat

\begin{tabular}{|c|c|c|c|c|c|c|c|c|}
\hline \multirow{3}{*}{ Tindakan } & \multicolumn{4}{|c|}{ Kelompok Perlakuan } & \multicolumn{4}{|c|}{ Kelompok Kontrol } \\
\hline & \multicolumn{2}{|c|}{ Pretest } & \multicolumn{2}{|c|}{ Posttest } & \multicolumn{2}{|c|}{ Pretest } & \multicolumn{2}{|c|}{ Posttest } \\
\hline & f & $\%$ & $\mathbf{f}$ & $\%$ & $\mathbf{f}$ & $\%$ & f & $\%$ \\
\hline Baik & 0 & 0 & 17 & 68 & 0 & 0 & 0 & 0 \\
\hline Cukup & 0 & 0 & 8 & 32 & 0 & 0 & 0 & 0 \\
\hline Kurang & 25 & 100 & 0 & 0 & 25 & 100 & 25 & 100 \\
\hline total & 25 & 100 & 25 & 100 & 25 & 100 & 25 & 100 \\
\hline \multicolumn{2}{|c|}{ Uji Wilcoxon sign rank test } & & \multirow{2}{*}{\multicolumn{2}{|c|}{$\mathrm{p}=0,000$}} & & & \multirow{2}{*}{\multicolumn{2}{|c|}{$\mathrm{p}=1,000$}} \\
\hline Uji Mann Whitr & & & & & 00 & & & \\
\hline
\end{tabular}

menunjukkan sebagian besar responden saat pre test berpengetahuan kurang yaitu sebanyak 23 anak (92\%), sedangkan pada saat post test sebagian besar responden berpengetahuan kurang yaitu sebanyak 23 anak (92\%). Setelah dilakukan Wilcoxon sign rank testdidapatkan nilai $\mathrm{p}=0,671(\mathrm{p}>0,05)$ artinya tidak ada perbedaan pengetahuan yang signifikan saat pre test dan post test. Hasil uji Mann Whitney U Test pada post test pengetahuan kelompok perlakuan dan kelompok kontrol didapatkan nilai $p=0,000(p<0,05)$ artinya terdapat perbedaan pengetahuan yang signifkan antara kelompok perlakuan dan kelompok kontrol [Tabel 2].

Tindakan responden mengenai pertolongan pertama pada luka, seluruh responden pada kelompok perlakuan belum dapat melakukan tindakan penanganan luka terbuka pada saat pre test. Hasil post test menunjukkan sebagian besar anak dapat melakukan tindakan penanganan luka terbuka dengan baik yaitu sebanyak 17 anak (68\%). Setelah dilakukan uji wilcoxon sign rank test didapatkan nilai $\mathrm{p}=0,000(\mathrm{p}<0,05)$ artinya ada perbedaan tindakan

\section{PEMBAHASAN}

4.1 Pengaruh metode role play terhadap pengetahuan pertolongan pertama luka pada anak usia sekolah

Hasil pre test pengetahuan sebagian besar responden pada kelompok perlakuan dan kelompok kontrol berada pada kategori kurang. Setelah dilakukan pendidikan kesehatan metode role play pada kelompok perlakuan, hasil post test menunjukkan terjadi peningkatan pengetahuan yang signifikan. Sedangkan pada kelompok kontrol, hasil post test menunjukan tidak terjadi peningkatan pengetahuan yang signifikan. Hasil pre test sebagian besar pengetahuan responden pada kelompok perlakuan berada pada kategori kurang dan sebagian kecil memiliki pengetahuan cukup. Sedangkan pada kelompok kontrol, hasil pre test menunjukkan sebagian besar pengetahuan responden berada pada kategori kurang dan sebagian kecil berada pada kategori cukup. 
Pengetahuan terdiri dari 6 domain yaitu tahu, memahami, aplikasi, analisis, sintesis dan evaluasi. Sebelum diberikan pendidikan kesehatan metode role play, Pada domain tahu, siswa paling banyak menjawab pertanyaan dengan benar pada soal nomer 23 dan 25 yaitu sebanyak 17 orang dengan tema soal tentang jenis luka dan dampak yang ditimbulkan oleh luka. Pada domain memahami, siswa paling banyak menjawab pertanyaan dengan benar pada soal nomer 2 dan 14 yaitu sebanyak 15 orang dengan tema soal tentang prinsip pertolongan pertama dan alat untuk merawat luka. Pada domain aplikasi, siswa paling banyak menjawab pertanyaan dengan benar pada soal nomer 11 yaitu sebanyak 19 orang dengan tema soal tentang cara melakukan perawatan luka yang benar. Pada domain analisis, siswa paling banyak menjawab pertanyaan dengan benar pada soal nomer 29 yaitu sebanyak 10 orang dengan tema soal tentang membedakan cara perawatan pada tiap jenis luka. Pada domain sintesis, siswa paling banyak menjawab pertanyaan dengan benar pada soal nomer 24 yaitu sebanyak 15 orang dengan tema soal tentang alternatif alat yang digunakan untuk membersihkan luka. Pada domain evaluasi, siswa paling banyak menjawab pertanyaan dengan benar pada soal nomer 10 yaitu sebanyak 19 orang dengan tema soal tentang justifikasi bahaya yang ada dilingkungan sekolah. Setelah diberikan pendidikan kesehatan metode role play, seluruh siswa mengalami peningkatan skor pertanyaan yang dijawab dengan benar pada semua domain pengetahuan.

Menurut (17) anak umur 10-12 tahun memiliki intensitas daya ingat yang besar dan kuat, daya memorisasi yang baik sehingga anak mampu memuat jumlah materi ingatan paling banyak. Jika suatu pengetahuan diberikan kepada siswa secara detail, siswa cenderung akan menerima dan mengingat dengan baik. Hasil post test menunjukkan adanya peningkatan responden yang menjawab benar pada ke enam domain pengetahuan. Berdasarkan teori (13) dalam (18) pengetahuan dipengaruhi oleh faktor predisposisi, yaitu umur, jenis kelamin, pendidikan dan status ekonomi. Berdasarkan teori tersebut dan data demografi, Seluruh responden pada penelitian ini adalah anak umur 10-12 tahun. Pada masa umur 10-12 tahun, anak berada dalam puncak perkembangan sehingga mudah untuk dibimbing, diarahkan dan ditanamkan kebiasaan yang baik (12). Tahap perkembangan kognitif anak usia sekolah berada pada concrete operational stage. Pada tahap ini anak mampu menggunakan proses berpikir untuk menghubungkan serangkaian kejadian saat mengalami suatu peristiwa. Concrete operational stage ditandai dengan penalaran induktif, tindakan logis, dan pikiran konkrit yang reversible. Anak mengalami kemajuan dalam membuat penilaian berdasarkan apa yang mereka lihat, jika pada tahap ini anak tidak mendapatkan suatu pendidikan kesehatan seperti cara melakukan penanganan pada luka terbuka, maka anak tidak akan bisa melakukan penanganan luka ketika suatu saat anak mengalami luka. (19).
Menurut (17) anak umur 10-12 tahun memiliki intensitas daya ingat yang besar dan kuat, daya memorisasi yang baik sehingga anak mampu memuat jumlah materi ingatan paling banyak. Jika suatu pengetahuan diberikan kepada siswa secara detail, siswa cenderung akan menerima dan mengingat dengan baik. Berdasarkan teori tersebut, perubahan pengetahuan responden pada saat pre test yang sebagian besar berada pada kategori kurang dan saat post test sebagian besar pengetahuan responden berada pada kategori cukup, dapat terjadi karena responden dalam penelitian ini adalah anak umur 1012 tahun, dimana anak memiliki daya ingat yang kuat sehingga mengakibatkan nilai post test pada kelompok perlakuan meningkat.

Berdasarkan teori Precede Proceed menyatakan bahwa faktor pendorong yang mempengaruhi kemampuan individu salah satunya yakni orang tua (6). Responden memiliki latar belakang keluarga yang berbeda-beda. Tingkat pengetahuan responden kelompok perlakuan dan kelompok kontrol yang berada pada kategori cukup saat pre test, dilihatdari data demografi responden tersebut memiliki orang tua yang berpendidikan S1, anak yang orang tuanya berpendidikan tinggi biasanya mendapat pembelajaran yang baik di rumah daripada yang orang tuanya berpendidikan rendah, oleh karena itu responden memiliki pengetahuan yang cukup pada saat pre test. Sedangkan faktor pendidikan berjalan searah dengan umur. Apabila umur meningkat maka pendidikan juga meningkat hal ini mendukung untuk meningkatkan pengetahuan anak (20)

Menurut (21) proses belajar merupakan perubahan kemampuan dari subyek belajar serta dipengaruhi oleh beberapa faktor antara lain yakni alat bantu belajar, metode, dan teknik pembelajaran yang digunakan. Untuk mendapatkan suatu pengetahuan diperlukan suatu metode pendidikan kesehatan yang tepat dan sesuai dengan tahap perkembangan anak usia sekolah yaitu bermain. Menurut Freud dalam (19) tahap perkembangan anak usia sekolah ini berada pada latent periode. Pada masa latent periode ini, anak-anak membina hubungan dengan teman sebaya, energi fisik dan psikisnya diarahkan untuk bermain dan mendapatkan pengetahuan. Apabila selama latent periode ini anak tidak diarahkan untuk mendapatkan pengetahuan dengan benar maka anak akan kehilangan kesempatan untuk memperoleh pengetahuan dasar yang seharusnya diperoleh.

Pengetahuan merupakan hasil dari tahu dan terjadi setelah orang melakukan pengindraan terhadap suatu objek tertentu. Pengindraan terjadi melalui pengindraan manusia, yaitu indra penglihatan, pendengaran, penciuman, perasa dan peraba. Sebagian besar pengetahuan manusia diperoleh melalui mata dan telinga (6). Salah satu faktor yang mempengaruhi meningkatnya pengetahuan adalah adanya informasi yang telah diterima (22). Berdasarkan teori tersebut dan data demografi, anak yang pernah memperoleh informasi mengenai penanganan luka terbuka sebelumnya 
memiliki pengetahuan yang berada pada kategori cukup sedangkan anak yang tidak pernah mendapatkan informasi penanganan luka memiliki pengetahuan yang berada pada kategori kurang pada saat pre test.

Salah satu permasalahan dalam keefektifan pemberian informasi adalah kurangnya minat dalam penyerapan informasi. Akibat yang ditimbulkan adalah bosan, mengantuk dan enggan menerima informasi yang disampaikan. Sehingga minat adalah faktor penting yang harus ditingkatkan sebelum pemberian informasi. Salah satu cara agar minat dalam menerima informasi meningkat adalah menggunakan media dalam proses pemberian informasi. Pemberian informasi yang efektif untuk anak sekolah dasar salah satunya adalah dengan menggunakan media pembelajaran dengan metoda belajar sambil bermain (23). Oleh karena itu peneliti menggunkan metode role play sebagai metode pendidikan kesehatan tentang pertolongan pertama pada luka, dimana anak dapat bermain sekaligus belajar sehingga tidak terjadi kebosanan dan tumbuh minat pada anak saat belajar.

Penelitian ini menggunakan metode bermian peran (role play). Metode bermain peran (role play) merupakan suatu aktivitas pembelajaran terencana yang dirancang untuk mencapai tujuan-tujuan pendidikan yang dipakai untuk menjelaskan peranan, sikap, tingkah laku, nilai dengan tujuan menghayati perasaan, sudut pandang dan cara berpikir orang lain (24). Metode bermain peran (role play) adalah salah satu jenis metode dari simulasi yang pelaksanaanya melibatkan lebih dari satu panca indra. Dalam bermain peran, siswa dituntut untuk berperan aktif, sehingga mendapatkan pengalaman dari bermain peran tersebut. Metode ini dapat digunakan untuk meningkatkan diskusi, mempraktikkan keterampilan, mengalami, dan merasakan suatu peristiwa tertentu. Dengan memainkan peran situasi kehidupan nyata, orang akan lebih mudah mengerti penyebab masalah mereka dan hasil perilaku mereka sendiri (25).

Tujuan dari bermain peran (role play) adalah agar partisipan dapat memahami perasaan orang lain, menempatkan diri pada situasi orang lain, mengerti dan menghargai perbedaan pendapat, sehingga mereka dapat menghayati peran yang dimainkan, mampu menempatkan diri dalam situasi orang lain yang dikehendaki fasilitator. Menurut (15), ada beberapa kelebihan dari metode role play yaitu : dapat berkesan dengan kuat dan tahan lama dalam ingatan anak, disamping menjadi pengalaman yang menyenangkan juga memberi pengetahuan yang melekat dalam memori otak; mendorong keterlibatan peserta yang mendalam; membangkitkan pengertian, prasangka dan persepsi; memusatkan perhatian peserta pada aspek-aspek tertentu yang dikehendaki; mampu menumbuhkan dan meningkatkan minat belajar dalam suatu proses pembelajaran.

Menurut (16) Metode role play merupakan metode pembelajaran yang melibatkan siswa secara aktif dalam bentuk drama yang diharapkan dapat mempermudah pemahaman siswa terhadap materi pembelajaran, dan mencapai tujuan pembelajaran. Menurut (26) model bermain peran merupakan suatu cara penguasaan bahan-bahan pelajaran melalui imajinasi dan penghayatan peserta didik. Menurut (27) dalam penelitiannya mengungkapkan bahwa dalam role playing peserta didik dituntut menjadi pribadi yang imajinatif, mempunyai prakarasa, mempunyai minat yang luas, mandiri dalam berfikir, ingin tahu, penuh energi dan percaya diri.

Analisis pada [tabel 2] menunjukkan hasil post test sebagian besar pengetahuan responden pada kelompok perlakuan berada pada kategori cukup dan sebagian kecil memiliki pengetahuan yang berada pada kategori baik. Pada kelompok kontrol tidak terjadi peningkatan pengetahuan pada saat post test, dikarenakan kelompok kontrol tidak diberikan informasi tentang penanganan luka terbuka. Hal ini sesuai dengan teori yang mengatakan bahwa pendidikan kesehatan dapat mengubah perilaku kurang sehat menjadi sehat yang artinya dapat mengubah pengetahuan responden yang kurang baik menjadi baik (28). Menurut (29) bahwa perubahan pengetahuan dan sikap atau perubahan perilaku salah satunya dipengaruhi oleh media dalam penyuluhan. Adanya media dalam penyuluhan tersebut dapat mempengaruhi pengetahuan, sikap yang selanjutnya dapat mempengaruhi praktik itu sendiri.

Menurut (15) dalam penelitiannya yang berjudul perbandingan efektifitas penyuluhan kesehatan gigi metode dongeng (story telling) dengan metode bermain peran (role play) pada siswa kelas 3 sekolah dasar didapatkan hasil yaitu metode bermain peran (role play) sebagai metode penyuluhan kesehatan gigi dan mulut merupakan metode yang efektif untuk meningkatkan pengetahuan. Melalui pembelajaranmenggunakan metode role play ini siswa dilibatkan secara aktif dalam situasi yang menyenangkan. Kejenuhan dan kebosanan siswa dapat teratasi melalui peran yang dimainkan. Minat siswa dalam pembelajaran dapat terakomodasi saat bermain peran. Siswa tidak hanya aktif secara fisik, tetapi juga secara mental aktif yang meliputi kegiatan bertanya, berpendapat, menjawab pertanyaan dan menanggapi pendapat. Sehingga pada saat post test pengetahuan reponden dapat meningkat.

4.2 Pengaruh metode role play terhadap tindakan pertolongan pertama luka pada anak usia sekolah

Hasil pre test tindakan seluruh responden pada kelompok perlakuan dan kelompok kontrol berada pada kategori kurang. Jika dikaitkan dengan data demografi, sebagian besar responden tidak pernah mendapatkan informasi mengenai penanganan luka, sehingga pengetahuan responden tentang penanganan luka tidak ada. Point tindakan yang masih banyak tidak dilakukan oleh responden pada saat pre test yaitu point 1,5 dan 6 yaitu cuci tangan sebelum, menutup luka dengan menggunakan kassa steril/plester dan cuci tangan sesudah melakukan penanganan luka, hal ini dikarenakan responden belum mengetahui langkah-langkah melakukan 
tindakan penanganan luka yang baik dan benar. Sesuai dengan teori menurut (6), tindakan seseorang dipengaruhi oleh pengetahuan. Berdasarkan hasil studi pendahuluan yang dilakukan, siswa mengatakan tidak pernah diajarkan tentang cara melakukan penanganan luka oleh guru. Menurut teori yang di kemukakan oleh (30), bahwa salah satu faktor yang mempengaruhi pengetahuan adalah informasi. Infromasi akan memberikan pengaruh pada pengetahuan dan pengetahuan akan mempengaruhi tindakan seseorang.

Penelitian ini menggunakan metode role play. Metode bermain peran (role play) adalah salah satu jenis metode dari simulasi yang pelaksanaanya melibatkan lebih dari satu panca indra. Dalam bermain peran, siswa dituntut untuk berperan aktif, sehingga mendapatkan pengalaman dari bermain peran tersebut. Metode ini dapat digunakan untuk meningkatkan diskusi, mempraktikkan keterampilan, mengalami, dan merasakan suatu peristiwa tertentu. Dengan memainkan peran situasi kehidupan nyata, orang akan lebih mudah mengerti penyebab masalah mereka dan hasil perilaku mereka sendiri (25) Pengetahuan merupakan hasil tahu yang diperoleh seseorang setelah mengadakan pengindraan terhadap suatu obyek tertentu, pengetahuan merupakan domain yang sangat penting untuk terbentuknya tindakan seseorang (12). Metode role play merupakan salah satu upaya untuk meningkatkan tindakan penanganan luka terbuka pada anak usia sekolah dengan memerankan/mendramakan cara melakukan penanganan luka terbuka dimana responden ikut serta langsung dalam memerankan peranan (31). Bermain peran dapat dilakukan dengan dua pendekatan, yaitu terstruktur dan spontanitas. Pendekatan terstruktur menekankan proses belajar dengan cara mengobservasi, mempraktikan, menirukan (konseptualisasi) dan membagi pengalaman selama bermain peran (analisis). Pendekatan spontan lebih menekankan pada konseptualisasi tetapi meminimalkan analisis (14).

Menurut (32) Presentase keberhasilan menyerap informasi dan menyimpannya dalam memori ketika belajar yaitu: $10 \%$ dari apa yang kita baca, 20\% dari apa yang kita dengar, 30\% dari apa yang kita lihat, 50 $\%$ dari apa yang kita lihat dan dengar, $70 \%$ dari apa yang kita katakan dan $90 \%$ dari apa yang kita katakan dan kerjakan. Tahapan dalam role play mengarahkan siswa untuk memerankan sesuai dengan skenario yang berisi informasi mengenai cara melakukan penanganan luka terbuka. Pada tahapan ini siswa dapat menyerap informasi sebesar $90 \%$ karena siswa langsung mengatakan dan mengerjakan yang disampaikan melalui skenario.Pendidikan kesehatan metode role play salah satu upaya untuk meningkatkan tindakan penanganan luka terbuka. Siswa terlibat langsung dalam kegiatan bermain peran yang meningkatkan daya ingat dan analisis cara melakukan penanganan luka melalui tahapan dalam role play sehingga siswa bisa melakukan tindakan penanganan luka terbuka dengan baik dan benar. Peningkatan nilai yang terjadi setelah diberikan pendidikan kesehatan menggunakan metode role play. Berdasarkan teori (6) dimana terdapat tingkatan dalam tindakan yaitu respon terpimpin (guide respons), dimana responden melakukan sesuatu sesuai dengan urutan yang benar sesuai dengan contoh yang telah diberikan.

Pada hasil post test, tindakan yang tidak dilakukan oleh siswa adalah point 5 dan 6 yaitu menutup luka dengan menggunakan kassa steril/plester dan cuci tangan sesudah melakukan penanganan luka. Hal ini bisa disebabkan oleh berbagai macam faktor. Menurut (33) ada dua faktor yang dapat mempengaruhi prestasi belajar siswa, yaitu faktor internal dan eksternal faktor internal berkaitan dengan segala hal yahng ada pada diri siswa meliputi kesehatan dan cacat tubuh, intelegensi atau kecerdasan (kecerdasan intelektual, emosional, dan spiritual), perhatian, sikap, minat, bakat, motivasi, kelelahan, dan disiplin belajar. Sedangkan faktor eksternal berkaitan dengan segala hal yang datang dari luar individu, baik melalui cara orang tua mendidik, hubungan antar anggota keluarga, latar belakang budaya, metode mengajar, media pelajaran, kurikulum, hubungan siswa dengan siswa dan kegiatan siswa dalam masyarakat. Pada kelompok kontrol tidak terjadi peningkatan tindakan pada saat post test, dikarenakan kelompok kontrol tidak diberikan pendidikan kesehatan tentang pertolongan pertama pada luka.

\section{KESIMPULAN}

Pendidikan kesehatan metode role play dapat meningkatkan pengetahuan dan tindakan anak usia sekolah tentang pertolongan pertama pada luka. Diharapkan bagi pihak sekolah untuk menyediakan fasilitas UKS dengan alat dan bahan penanganan luka yang lengkap dan guru yang mengelola UKS. Metode role play dapat juga digunakan oleh pihak sekolah sebagai alternatif metode pembelajaran untuk meningkatkan hasil belajar siswa terutama yang berkaitan dengan pertolongan pertama pada luka. Perawat komunitas dan perawat anak dalam perannya sebagai edukator dapat menjadikan metode role play sebagai metode dalam memberikan pendidikan kesehatan pada anak usia sekolah.

\section{UCAPAN TERIMA KASIH}

Kami mengucapkan terima kasih kepada Kepala Sekolah Dasar Negeri 2 Penimbung untuk izin dan penerimaan kami untuk mengambil data sebagai bahan penelitian dan semua siswa kelas 4,5 dan 6 yang telah bersedia menjadi responden.

\section{DAFTAR PUSTAKA}

1. Badan Nasional Penanggulangan Bencana. Definisi dan Jenis Bencana - Badan Nasional Penanggulangan Bencana. 2017.

2. Masykur AM. Potret Psikososial Korban Gempa 27 Mei 2006 (Sebuah Studi Kualitatif di 
Kecamatan Wedi dan Gantiwarno, Klaten). 2006;3(1):36-44.

3. Dirgantara, Candra Ria et al. Kartu Dokter Kecil Keluarga Indonesia (Dokkelin) Sebagai Media Permainan Edukatif Untuk Anak Usia Sekolah Dasar. J Ilm Mhs. 2013;3 No.1(1):7-10.

4. Riskesdas. RISET KESEHATAN DASAR. Ris Kesehat Dasar 2013. 2013;

5. Chang SSM, Symons RCA, Ozanne-smith J. Child road traf fi c injury mortality in Victoria, Australia ( 0 - 14 years ), the need for targeted action. Injury. 2018;49(3):604-12.

6. Notoatmodjo S. Ilmu Perilaku Kesehatan. Jakarta: Rineka Cipta; 2010.

7. Azwar S. Sikap Manusia: Teori dan Pengukurannya. Yogyakarta: Pustaka Belajar; 2009.

8. Rizky AS, Edy R. Pengaruh Penerapan Metode Simulasi Terhadap Kecakapan Pertolongan Pertama Pada Kedaruratan (P3K) Pada Siswa Tunagrahita Di SLB/C Taman Pendidikan Dan Asuhan JEMBER. 2015;7.

9. Tamara Y, Hendri P, Angina W. Hal ini sejalan dengan penelitian Hendri dan Putra (2015) bahwa sebagian besar responden yang pengetahuannya kurang belum pernah mendapatkan informasi penanganan kegawatdaruratan secara lengkap dari sumber informasi formal. 2015;

10. Palang Merah Indonesia. Pedoman Pertolongan Pertama. edisi 4. Markas Pusat Palang Merah Indonesia; 2009.

11. Triananda K. Pentingnya Pengetahuan P3K Untuk Anak - BeritaSatu.com. 2013.

12. Notoatmodjo S. Promosi Kesehatan dan Perilaku Kesehatan. Jakarta: Rineka Cipta; 2012.

13. Green L, Kreuter M. Health Promotion Planning. An Educational and Environmental Approach. Mountain View: Mayfield Publishing Co.; 1991.

14. Nursalam, Efendi F. Pendidikan Dalam Keperawatan. Jakarta: Salemba Medika; 2008.

15. Khairani R. Perbandingan Efektifitas Penyuluhan Kesehatan Gigi Metode Dongeng (Storytelling) Dengan Metode Bermain Peran (Role play) Pada Siswa Kelas 3 Sekolah Dasar. 2017;3-5.

16. Yuliana A. Implementasi Metode Role play Dalam Peningkatan Hasil Belajar dan Motivasi Belajar Siswa Sekolah Dasar Pada Mata Pelajaran IPA Tentang Posisi Bulan dan Kenampakan Bumi Dari Hari ke Hari Di Kelas IV SD Negeri Bringin 01. Universitas Kristen Satya Wacana Salatiga; 2012.

17. Chussurur, Mifta Hidayat, Thulus Agustin RW.
Pengaruh pemberian cerita melalui media audiovisual terhadap. Universitas Sebelas Maret Surakarta; 2011.

18. Nursalam. Metodologi Penelitian Ilmu Keperawatan. 4th ed. Jakarta: Salemba Medika; 2016.

19. Wong SD., Winkelstein, Hockenberry. Buku Ajar Keperawatan Pediatrik. edisi 6. 2009.

20. Febriani K. Pengaruh Pendidikan Kesehatan Terhadap Peningkatan Pengetahuan Dalam Pemilihan Jajan Pada Anak Usia Sekolah 7-9 Tahun Desa Ngantru Kecamatan Ngantang Kabupaten Malang. 2018;3:481-91.

21. Sunaryo. Psikologi untuk Keperawatan. Jakarta: EGC; 2004.

22. Lestari SAW. Pengaruh Penyuluhan Jajan Sehat Terhadap Pengetahuan dan Sikap Siswa di Madrasah Ibtidaiyah Gonilan Kartasura. Universitas Muhammadiyah Surakarta; 2015.

23. Fadhilah D, Ninuk T, Hartini S, Gunawan IMA. Efektifitas Penyuluhan tentang Sayuran Menggunakan Media “ Kartu Sayuran ” terhadap Peningkatan Pengetahuan Siswa Sekolah Dasar. 2017;15(September):100-5.

24. Ariwitari N., Kristiantari MG. Pengaruh Metode Pembelajaran Role playing Berbantuan Media Audio Visual Terhadap Hasil Belajar PKN kelas V SD Gugus 1 Tampaksiring. 2014;

25. Maulidiyah SR. Efektivitas Metode Bermain Peran Terhadap Tingkat Pengetahuan HIV / AIDS ( Studi di SMK Nusa Bhakti Semarang ). Universitas Negeri Semarang; 2015.

26. Hamdayama J. Model dan Model Pembelajaran yang Kreatif dan Berkarakter. Bogor: Ghalia Indonesia; 2014

27. Baroro K. Upaya Meningkatkan Nilai-Nilai Karakter Peserta Didik Melalui Penerapan Metode Role playing. Jakarta: Rineka Cipta; 2011.

28. Effendi N. Dasar-Dasar Keperawatan Kesehatan Masyarakat. Edisi 2. Jakarta: EGC; 2012.

29. Edyati L. Pengaruh Penyuluhan Kesehatan dengan Media Media Video Terhadap Pengetahuan dan Sikap Personal Hygiene Siswa SD Negeri 1 Kepel Pengasih Kulon Progo. 2014;

30. Hendra A. Faktor-Faktor Yang Mempengaruhi Pengetahuan. Jakarta: Pustaka Sinar Harapan; 2008.

31. Kartini T. Penggunaan Metode Role playing untuk Meningkatkan Minat Siswa dalam Pembelajaran. 2007.

32. Irianti YNE. Pengaruh Metode Role play Terhadap Self Care Management Resiko Jatuh Pada Lansia Di Rw II Kelurahan Manyar Sabrangan Surabaya. Universitas Airlangga; 
W. SAPUTRA ET AL.

2015.

33. Sugihartono, Fathiyah KN, Harahap F, Setiawati
FA, Nurhayati SR. Psikologi Pendidikan. Yogyakarta: UNY Press; 2007. 